\title{
Kinetics and Mechanism of the Reaction of Coherently Synchronized Oxidation and Dehydrogenation of Cyclohexane by Hydrogen Peroxide
}

\author{
S. Aghamammadova ${ }^{1}$, I. Nagieva ${ }^{2}$, L. Gasanova ${ }^{1}$, T. Nagiev ${ }^{1,2, a}$ \\ ${ }^{1}$ Nagiev Institute of Catalysis and Inorganic Chemistry, National Academy of Sciences of Azerbaijan \\ ${ }^{2}$ Baku State University, Azerbaijani Republic
}

\begin{abstract}
Inducing effect of hydrogen peroxide on synchronous oxidation reaction is accompanied by the occurrence of two interconnected and interacting reactions. The reaction of $\mathrm{H}_{2} \mathrm{O}_{2}$ decomposition (primary) generates the leading active ${ }^{\circ} \mathrm{OH}$ and $\mathrm{HO}_{2}$ free radicals in a system. During the interaction of active and free radicals with the substrate, the conversion of the substrate occurs in the secondary reaction, coherently-synchronized with the primary one.

The mechanism of such coherently synchronized reactions is being examined in the process of cyclohexane oxidation with hydrogen peroxide in homogeneous and heterogeneous systems.

The process of coupling dehydrogenation of cyclohexane to cyclohexene and cyclohexadiene with hydrogen peroxide was carried out without catalyst. This process was also carried out at a fairly low temperature in a heterogeneous catalytic system.

Biomimetic catalyst, which simulates the basic functions of the enzyme group of oxidoreductase - catalase and monooxygenase, was used as the catalyst here. Characterised by its highly active and selective action these biomimetic catalysts are synthesized based on iron-porphyrin complexes simulating the active component of cytochrome P-450.

Based on this experimental researches, the complex reaction, consisting of parallel-sequential oxidation and dehydrogenation reactions, which are coherently synchronized, proceeds during the process of cyclohexane oxidation with biomimetic catalyst. Depending on the reaction parameters it is possible to deliberately adjust the direction of oxidation reaction and reaction rate.
\end{abstract}

\section{INTRODUCTION}

Inducing effect of hydrogen peroxide on synchronous oxidation reaction is accompanied by the occurrence of two interconnected and interacting reactions $[1,2]$. The reaction of $\mathrm{H}_{2} \mathrm{O}_{2}$ decomposition (primary) generates the leading active ${ }^{\circ} \mathrm{OH}$ and $\mathrm{HO}_{2}{ }_{2}$ free radicals in a system. During the interaction of active and free radicals with the substrate, the conversion of the substrate occurs in the secondary reaction, coherently-synchronized with the primary one [3].

The mechanism of such coherently synchronized reactions is being examined in the process of cyclohexane oxidation with hydrogen peroxide in homogeneous and heterogeneous systems. The cyclohexane oxidation is the most commonly studied process, where the valuable for organic synthesis compounds are achieved during oxidative dehydrogenation or during oxidation [4-7]. The implementation of thermodynamically hindered reactions is of great interest for petrochemical and organic synthesis. Among them the reactions of partial dehydrogenation of cyclohexane to cyclohexene and cyclohexadiene should be mentioned.

$$
\begin{aligned}
& \Delta G, \mathrm{~kJ} / \mathrm{mol} \\
& \mathrm{C}_{6} \mathrm{H}_{12} \rightarrow \mathrm{C}_{6} \mathrm{H}_{10}+\mathrm{H}_{2} \\
& \\
& \mathrm{C}_{6} \mathrm{H}_{10} \rightarrow \mathrm{C}_{6} \mathrm{H}_{8}+\mathrm{H}_{2}
\end{aligned}
$$

It is of course more beneficial in terms of energy to carry out such reactions in conjunction with other reactions, in this case, with the reaction of hydrogen peroxide decomposition.

\section{RESULTS AND DISCUSSION}

The process of coupling dehydrogenation of cyclohexane to cyclohexene and cyclohexadiene with hydrogen peroxide was carried out without catalyst [8].

The reaction was examined at a temperature range of $450-650{ }^{\circ} \mathrm{C}$ at various flow rates and ratios of starting reactants. The process was of sequential and autocatalytic nature with the period of selfacceleration (kinetic curves for cyclohexadiene and benzene), as shown in Figure 1. Under optimum conditions, the yield of cyclohexene was up to 
$19.4 \%$, of cyclohexadiene was $3.4 \%$ and benzene $2.4 \%$.

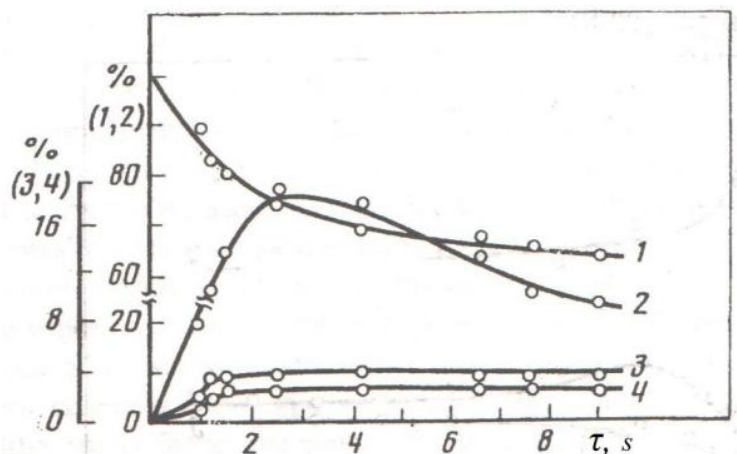

Figure 1. Kinetic curves for coupling dehydrogenation of cyclohexane:

1-cyclohexane; 2-cyclohexene; 3-benzene; 4cyclohexadiene

Kinetic curves show that the accumulation of cyclohexene as an intermediate product at the initial stage of the process increases up until the rate of its consumption and the rate of accumulation at the conventional contact time equal to $\tau=4.2 \mathrm{c}$, becomes equal, and cyclohexene concentration reaches a maximum value. Cyclohexene yield decreases with the further increase in contact time. The rate of formation of cyclohexene and cyclohexadiene initially increases, and reaches its maximum at the inflection point, which is typical for sequential reactions.

At a temperature range of $450-500{ }^{\circ} \mathrm{C}$ the cyclohexene is formed, with the increase in temperature range between $560{ }^{\circ} \mathrm{C}$ and $650{ }^{\circ} \mathrm{C}$ dehydrogenation products contain cyclohexadiene and benzene along with cyclohexene. These data also suggest that with further increase in temperature the ring-opening decomposition reaction of the cyclohexane occurs along with the process of the dehydrogenation. The consequence is the formation of gaseous products such as $\mathrm{H}_{2}, \mathrm{CO}_{2}, \mathrm{CH}_{4}, \mathrm{C}_{2} \mathrm{H}_{4} \ldots$

These experimental data aggregate show that in the studied range of variations by reaction parameters under the best conditions reaction proceeds in the direction of the oxidative dehydrogenation of cyclohexane achieving the yield of desired products $\mathrm{C}_{6} \mathrm{H}_{10}, \mathrm{C}_{6} \mathrm{H}_{8}$ и $\mathrm{C}_{6} \mathrm{H}_{6}-19,4 \%$; $3.4 \%$ and $2.4 \%$ respectively.

It is necessary to identify the nature of the interaction of $\mathrm{H}_{2} \mathrm{O}_{2}$ with the hydrocarbon, resulting with the formation of unsaturated compound under high-temperature oxidation conditions in order to identify the mechanism of dehydrogenation of cyclohexane.

A prerequisite for the coherently synchronized reactions to proceed in the reaction system is its quantitative characteristic defined by the determinant equation [1]:

$$
D=v\left(r_{1} / r_{a c}+r_{2} / r_{a c}\right)^{-1}
$$

where $\mathrm{r}_{1}$ and $\mathrm{r}_{2}$ - consumption rate of an actor $\left(\mathrm{H}_{2} \mathrm{O}_{2}\right)$ in the primary and secondary reactions respectively, $\mathrm{r}_{\mathrm{ac}}$ - consumption rate of an acceptor $\left(\mathrm{C}_{6} \mathrm{H}_{12}\right), v$ stoichiometric factor (in our case $v=1$ ). The value of the determinants calculated by using experimental data $\mathrm{D} \approx 0.1$ indicates the induced nature of dehydrogenation of cyclohexane.

Under the conditions of the hightemperature cyclohexane gas-phase oxidation with hydrogen peroxide, the reaction proceeds by a free radical mechanism, where active ${ }^{\circ} \mathrm{OH}$ and $\mathrm{HO}_{2} \cdot$ radicals are formed in the primary reaction - in the reaction of $\mathrm{H}_{2} \mathrm{O}_{2}$ decomposition, and they are consumed in the secondary one - in the dehydrogenation of cyclohexane. Considering that at a high temperature the concentration of $\mathrm{HO}_{2}{ }_{2}$ radicals in the reaction system is much higher than the concentration of ${ }^{\circ} \mathrm{OH}$ radicals [9], the $\mathrm{HO}_{2} \cdot$ radicals play a key role in the mechanism of the dehydrogenation:

\section{chain initiation}

$$
\mathrm{H}_{2} \mathrm{O}_{2} \rightarrow 2^{\circ} \mathrm{OH}-217,9 \mathrm{~kJ} / \mathrm{mol}
$$

chain propagation

$$
\begin{aligned}
& \mathrm{H}_{2} \mathrm{O}_{2}+^{\circ} \mathrm{OH} \rightarrow \mathrm{HO}_{2}+\mathrm{H}_{2} \mathrm{O}+107,7 \mathrm{~kJ} / \mathrm{mol} \\
& \left\{\mathrm{C}_{6} \mathrm{H}_{12}+\mathrm{HO}_{2} \rightarrow \mathrm{C}_{6} \mathrm{H}_{10}+\mathrm{H}_{2} \mathrm{O}+{ }^{\circ} \mathrm{OH}+40,17 \mathrm{~kJ} / \mathrm{mol}\right. \\
& \mathrm{C}_{6} \mathrm{H}_{10}+\mathrm{HO}_{2}^{\circ} \rightarrow \mathrm{C}_{6} \mathrm{H}_{8}+\mathrm{H}_{2} \mathrm{O}+{ }^{\circ} \mathrm{OH}+104,6 \mathrm{~kJ} / \mathrm{mol} \\
& \mathrm{C}_{6} \mathrm{H}_{8}+\mathrm{HO}_{2}^{\circ} \rightarrow \mathrm{C}_{6} \mathrm{H}_{6}+\mathrm{H}_{2} \mathrm{O}+{ }^{\circ} \mathrm{OH}+66,9 \mathrm{~kJ} / \mathrm{mol}
\end{aligned}
$$

\section{chain termination}

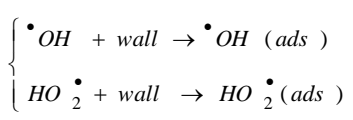

Each successive reaction of oxidative dehydrogenation of cyclohexane is a combination of chain initiation, propagation and termination stages. The system of kinetic equations, adequately describing the experimental data, is as follows [10]:

$$
\begin{aligned}
& -d\left[\mathrm{C}_{6} \mathrm{H}_{12}\right] / d \tau=k_{\text {eff } 1}\left[\mathrm{C}_{6} \mathrm{H}_{12}\right]\left[\mathrm{H}_{2} \mathrm{O}_{2}\right] \\
& -d\left[\mathrm{C}_{6} \mathrm{H}_{10}\right] / d \tau=k_{\text {eff } 1}\left[\mathrm{C}_{6} \mathrm{H}_{12}\right]\left[\mathrm{H}_{2} \mathrm{O}_{2}\right]-k_{\text {eff } 2}\left[\mathrm{C}_{6} \mathrm{H}_{10}\right]\left[\mathrm{H}_{2} \mathrm{O}_{2}\right] \\
& -d\left[\mathrm{C}_{6} \mathrm{H}_{8}\right] / d \tau=k_{\text {eff } 2}\left[\mathrm{C}_{6} \mathrm{H}_{10}\right]\left[\mathrm{H}_{2} \mathrm{O}_{2}\right]-k_{\text {eff } 3}\left[\mathrm{C}_{6} \mathrm{H}_{8}\right]\left[\mathrm{H}_{2} \mathrm{O}_{2}\right]
\end{aligned}
$$

where

$$
k_{\text {eff } 1}=10^{24,9} \exp (-264000 \quad R T) \mathrm{sm}^{3} / \mathrm{mol} \cdot \mathrm{s}
$$




$$
\begin{aligned}
& k_{\text {eff } 2}=10^{23,9} \exp (-222000 \quad R T) \mathrm{sm}^{3} / \mathrm{mol} \cdot \mathrm{s} \\
& k_{\text {eff } 3}=10^{22,8} \exp (-205000 \quad R T) \mathrm{sm}^{3} / \mathrm{mol} \cdot \mathrm{s}
\end{aligned}
$$

Examination of the process of coherently synchronized cyclohexane oxidation with hydrogen peroxide was carried out also at a fairly low temperature in a heterogeneous catalytic system. Biomimetic catalyst [11], which simulates the basic functions of the enzyme group of oxidoreductase catalase and monooxygenase, was used as the catalyst here. Characterised by its highly active and selective action these biomimetic catalysts are

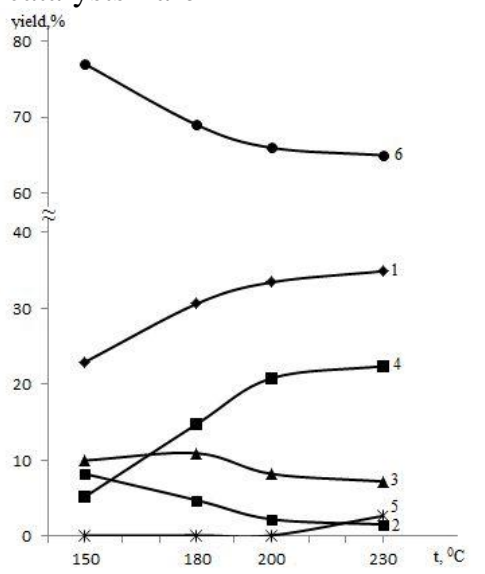

Figure 2. The dependence of the reaction yield of cyclohexane coherently synchronized oxidation with bio simulator per-

Table 1. The dependence of the reaction yield of cyclohexanol coherently synchronized oxidation with bio simulator per-

FTPhPFe(III)/ $/ \mathrm{Al}_{2} \mathrm{O}_{3}$ on the temperature: $\left[\mathrm{H}_{2} \mathrm{O}_{2}\right]=20 \%$,

\begin{tabular}{|c|c|c|c|c|c|c|c|c|c|c|c|}
\hline & \multicolumn{4}{|c|}{ Composition of feedstock, $\%$} & \multicolumn{7}{|c|}{ Composition of obtained reaction yield, $\%$} \\
\hline $\mathrm{t},{ }^{0} \mathrm{C}$ & $\mathrm{C}_{6} \mathrm{H}_{11} \mathrm{OH}$ & $\begin{array}{l}\text { 2-methyl } \\
\text { cyclohex } \\
\text { anol }\end{array}$ & $\begin{array}{c}\text { Hexanoi } \\
\text { c acid }\end{array}$ & $\begin{array}{l}\text { Hexanoic } \\
\text { acid } \\
\text { cyclohexy } \\
\text { l ester }\end{array}$ & $\mathrm{C}_{6} \mathrm{H}_{11} \mathrm{OH}$ & $\mathrm{C}_{6} \mathrm{H}_{10}$ & $\begin{array}{c}1,2 \text { cyclo } \\
\text { hexane } \\
\text { diol }\end{array}$ & $\begin{array}{c}1,3 \\
\text { cyclohexa } \\
\text { diene }\end{array}$ & $\begin{array}{l}\text { 2-methyl } \\
\text { cyclohexa } \\
\text { nol }\end{array}$ & $\begin{array}{l}\text { other } \\
\text { oxygena } \\
\text { tes }\end{array}$ & $\begin{array}{l}\text { Conversi } \\
\text { on }\end{array}$ \\
\hline 150 & 97,524 & 0,481 & 0,712 & 0,845 & 83,921 & 2,321 & 2,248 & 0,105 & 0,093 & 9,405 & 14,079 \\
\hline 180 & 97,524 & 0,481 & 0,712 & 0,845 & 78,186 & 7,841 & 2,875 & 0,145 & 0,583 & 10,753 & 19,814 \\
\hline 200 & 97,524 & 0,481 & 0,712 & 0,845 & 67,494 & 16,688 & 2,887 & 0,279 & 0,295 & 10,652 & 30,506 \\
\hline 230 & 97,524 & 0,481 & 0,712 & 0,845 & 55,255 & 30,374 & 2,0 & 0,1 & 0,641 & 10,271 & 42,745 \\
\hline
\end{tabular}

$$
V_{\mathrm{H}_{2} \mathrm{O}_{2}}=1,41 \mathrm{~mL} / \mathrm{h}, V_{\mathrm{C}_{6} \mathrm{H}_{12}}=0,9 \mathrm{~mL} / \mathrm{h}, \mathrm{C}_{6} \mathrm{H}_{11} \mathrm{OH}: \mathrm{H}_{2} \mathrm{O}_{2}=1: 1
$$

As shown in Figure 2 at the temperature up to $150-160{ }^{\circ} \mathrm{C}$ the reaction that mainly proceeds is cyclohexane oxidation reaction, forming cyclohexanol and cyclohexanone. At the temperature above $180^{\circ} \mathrm{C}$ the reaction of oxidative dehydrogenation of cyclohexane to cyclohexene (curve 4, Figure 2) begins to accelerate, respectively, the yield of cyclohexanol and cyclohexanone decreases. The sharp increase in the yield of cyclohexene along with the decrease in the yield of formed cyclohexanol indicates that at the temperature of $230{ }^{\circ} \mathrm{C}$ or higher cyclohexanol can also be converted into cyclohexene at lower concentrations of $\mathrm{H}_{2} \mathrm{O}_{2}$ in the reaction system. This conclusion is confirmed by the results of experimental studies of the process of cyclohexanol oxidation with hydrogen peroxide at a lower concentration (20\%) with the biomimetic catalyst, synthesized based on iron-porphyrin complexes simulating the active component of cytochrome P450 [12]. oxidation was carried out with heterogeneous biomimetic catalysts per-FTPhPFe(III)/ $/ \mathrm{Al}_{2} \mathrm{O}_{3}$ and $\mathrm{PPFe}(\mathrm{III}) / \mathrm{Al}_{2} \mathrm{O}_{3}$ at a temperature of $130-250{ }^{\circ} \mathrm{C}$ and a molar ratio $\mathrm{C}_{6} \mathrm{H}_{12}: \mathrm{H}_{2} \mathrm{O}_{2}=1: 1.7$ with $25 \%$ aqueous $\mathrm{H}_{2} \mathrm{O}_{2}$ solution. The results of these studies are shown in Figure 2. 
As it can be seen from the Figure 4 the reaction rate of oxidative dehydrogenation is higher than oxidation reaction rate and the yield of cyclohexane increases at the highest temperature $(\mathrm{t}=$ $\left.230^{\circ} \mathrm{C}\right)$

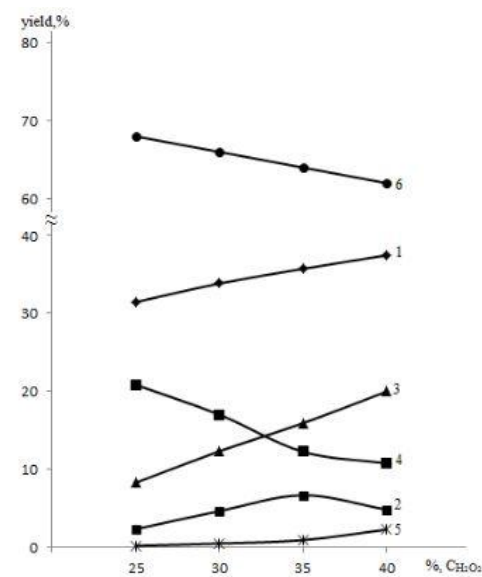

Figure 3. The dependence of the reaction yield of cyclohexane coherently synchronized oxidation with bio simulator per-FTPhPFe(III)/ $/ \mathrm{Al}_{2} \mathrm{O}_{3}$ on concentration $\mathrm{H}_{2} \mathrm{O}_{2}: \mathrm{t}=200^{0} \mathrm{C}, V_{\mathrm{H}_{2} \mathrm{O}_{2}}=1,41 \mathrm{~mL} / \mathrm{h}$, $V_{C_{6} H_{12}}=0,9 \mathrm{~mL} / \mathrm{h}$,

1- conversion; 2- cyclohexanol; 3- cyclohexanone; 4cyclohexene; 5 - cyclohexadiene; 6 - $\mathrm{O}_{2}$ yield

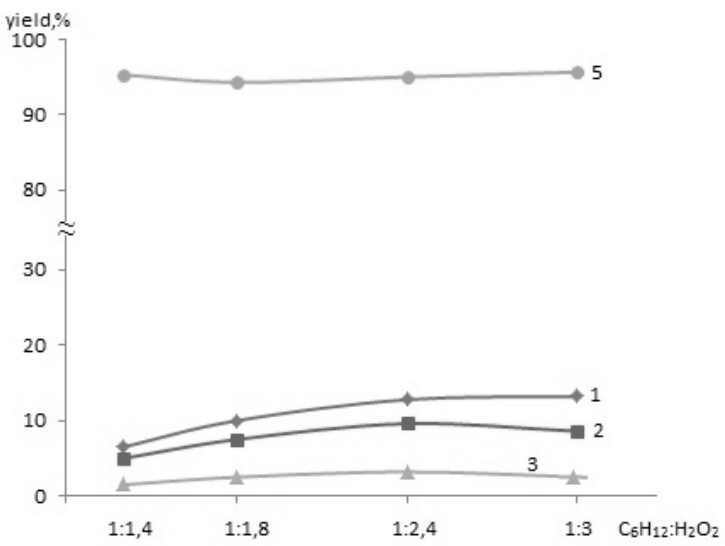

Figure 4. The dependence of the reaction yield of cyclohexane coherently synchronized oxidation over per-FTPhPFe(III)/ $/ \mathrm{Al}_{2} \mathrm{O}_{3}$ catalyst on $\mathrm{C}_{6} \mathrm{H}_{12}: \mathrm{H}_{2} \mathrm{O}_{2}$ ratio at the temperature $\mathrm{t}=150^{\circ} \mathrm{C}$,

$V_{\mathrm{H}_{2} \mathrm{O}_{2}}=1,41 \mathrm{~mL} / \mathrm{h}, V_{\mathrm{C}_{6} \mathrm{H}_{12}}=0,9 \mathrm{~mL} / \mathrm{h}$,

1- conversion; 2- cyclohexanol;

3- cyclohexanone; 4- O2yield

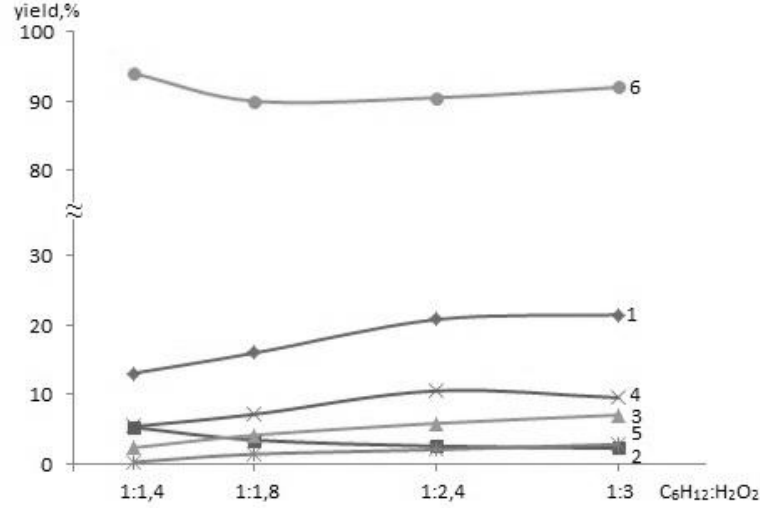

Figure 5. The dependence of the reaction yield of cyclohexane coherently synchronized oxidation over per-FTPhPFe(III)/ $/ \mathrm{Al}_{2} \mathrm{O}_{3}$ catalyst on $\mathrm{C}_{6} \mathrm{H}_{12}: \mathrm{H}_{2} \mathrm{O}_{2}$ ratio at the temperature $\mathrm{t}=230^{\circ} \mathrm{C}$,

$V_{\mathrm{H}_{2} \mathrm{O}_{2}}=1,41 \mathrm{~mL} / \mathrm{h}, V_{\mathrm{C}_{6} \mathrm{H}_{12}}=0,9 \mathrm{~mL} / \mathrm{h}$,

1- conversion; 2- cyclohexanol; 3- cyclohexanone; 4cyclohexene; 5- cyclohexadiene; 6- $\mathrm{O}_{2}$ yield

Thus, the complex reaction, consisting of parallel-sequential oxidation and dehydrogenation reactions, which are coherently synchronized, proceeds during the process of cyclohexane oxidation with biomimetic catalyst. Depending on the reaction parameters it is possible to deliberately adjust the direction of oxidation reaction and reaction rate.

It should be noted that in terms of the mechanism of each stage of this complex reaction of cyclohexane parallel-sequential oxidation with hydrogen peroxide with biomimetics, each oxidation reaction is carried out under inducing effect of hydrogen peroxide intermediates and consists of two coherently synchronized reactions - 1) catalase $\left(\mathrm{H}_{2} \mathrm{O}_{2}\right.$ decomposition reaction) and 2) monooxygenase (cyclohexane oxidation reaction) with biomimetic catalyst.

The probable mechanism of cyclohexane coherently synchronized oxidation, considering the parallel-sequential nature of oxidation and dehydrogenation, can be expressed by the general scheme [3]:

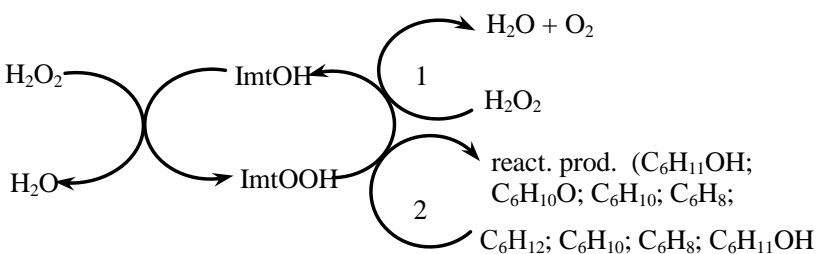

The mechanism of primary and secondary reactions proceeding over biomimetic catalyst is given: 
1) Mechanism of catalase reaction

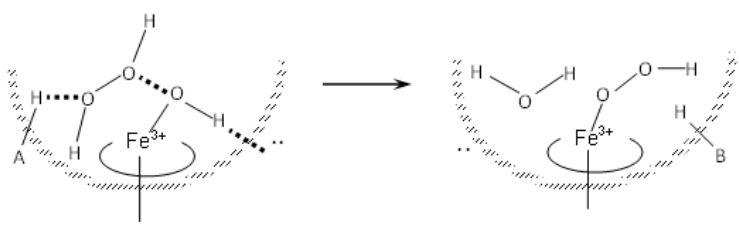

2) The mechanism of reaction of cyclohexane oxidation to cyclohexanol
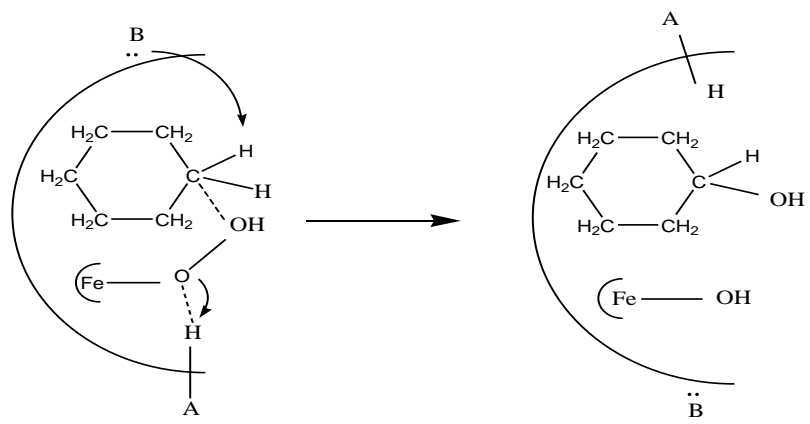

\section{CONCLUSION}

The scheme shows that formed active intermediate complex of hydroperoxide ( $\mathrm{ImtOOH})$, as in the case of free radical $\mathrm{HO}_{2}$, is the key active centre for coherent synchronization of catalase (primary) and monooxygenase (secondary) reactions. Coherently synchronized nature of the cyclohexane oxidation reaction follows from the experimental data (Figure 2 and 3). The changes in the catalase reaction rate (curve 6) and the rate of cyclohexane oxidation consumption (curve 1) are shown by the kinetic curves of Figures 2 and 3.

\section{REFERENCES}

[1]. T. M. Nagiev, Chemical Conjugation, M.: Nauka, 216 (1989)

[2]. T. M. Nagiev, The Theory of Coherent Synchronized Reactions: Chemical Interference Logics, International Journal of Chemical Engineering and Applications, 6, 5 (2015)

[3]. T. M. Nagiev, Coherent Synchronized Oxidation by Hydrogen Peroxide, Elsevier, Amsterdam, 325 (2007)

[4]. V. I. Timokhin, M. T. Lisovska, A. P. Pokucha, Kinetics and Catalysis, 41, 2, pp.179-185 (2000)

[5]. Eric C. Tyo, Chunrong Yin, Marcel Di Vece, etc. ACS Catal., 2, 11, 2409-2423 (2012)

[6]. Olsen M. H. N., Salomao G. C., Drago V. J. Supercrit. Fluids, 34, 2, 119-124 (2005)
[7]. Yu K. M. Kerry, Hummeida Ranya, Abutaki Afaf. Catal.Lett., 111, 1-2, 51-55 (2006)

[8]. T. M. Nagiev, F. G. Bayramov, Petrochemistry, 27, 2, 170-176 (1987)

[9]. T. M. Nagiev, S. I. Agaeva, F. G. Bayramov, Z. M. Nagieva, Azerb. Jour. Chem., 4, 16-21 (1997)

[10]. T. M. Nagiev, Vestn. Mosc. Univ. Ser. 2. Chemistry, 34, 3, 260-266 (1993)

[11]. T. M. Nagiev, L. M. Gasanova, S. Z. Zulfugarova, etc. Chemical Engineering Communications, An International Journal for Communication of Research. 190, 5-8, 726-748 (May-August 2003)

[12]. U. V. Nasirova, I. T. Nagieva, T. M. Nagiev, Journal of Materials Sciences and Engineering B2(4), 306-312 (2012) 